\title{
The sedimentology and tectonic significance of Devonian and Carboniferous terrestrial successions in Gaspé, Quebec
}

\author{
Brian R. Rust \\ Geology Department, University of Ottawa and Ottawa-Carleton Geoscience Centre \\ Ottawa, Ontario K1N 6N5, Canada \\ David A. Lawrence \\ B.P. Petroleum Development Limited, Britannic House, Moor Lane, London EC2Y 9BU \\ United Kingdom \\ and \\ Brian A. Zaitlin \\ Esso Resources Canada Limited, Calgary, Alberta T2P 0H6, Canada
}

Date Received June 24, 1988
Date Accepted August 15, 1988

The $5 \mathrm{~km}$-thick mid-Gaspé Devonian clastic wedge coarsens upwards from the shallow marine York River Formation through the Battery Point Formation (distal to proximal sandy alluvium) to gravelly proximal alluvium of the Malbaie Formation. Paleoflow was consistently northward, away from the rising Acadian mountains, but axial drainage switched from westward (York River, Lower Battery Point) to eastward (upper Battery Point, Malbaie) as the elevated source area migrated westward. This is attributed to dextral shearing of the North American continental margin due to collision between Avalonia and the St. Lawrence Promontory. Continued dextral shear ultimately caused impact between Avalonia and the New York Promontory, producing the Catskill wedge. In contrast, Devonian sediments in southern Gaspé are confined to smaller intermontane basins, with a mean southward paleoflow. The deposits comprise proximal alluvium (Lagarde, Pirate Cove, Fleurant Formations) and lacustrine sediments (Escuminac Formation).

In contrast with the broad Devonian clastic wedge, Carboniferous sediments in Gaspe predominantly accumulated on alluvial fans. Fan deposition is attributed to fault tectonics, predominantly dextral strike-slip along the Fundy Rift Zone as the inboard margin of Avalonia locked with the New York Promontory. However, Gaspe was peripheral to the main location of Carboniferous strike-slip shearing, and appears to have been mainly influenced by dip-slip faulting.

La Moyenne-Gaspésie recèle un prisme détritique dévonien granocroissant de $5 \mathrm{~km}$ d'épaisseur comprenant, de bas en haut, la Formation littorale de York River, la Formation de Battery Point (alluvions sablonneuses distales à proximales) et les alluvions graveleuses proximales de la Formation de la Malbaie. L'écoulement demeura consistant vers le nord, en s'éloignant des montagnes acadiennes qui étaient alors en cours de surrection, mais le drainage axial vira de l'ouest (York River, Batterie Point inférieure) vers l'est (Batterie Point supérieure, Malbaie) durant la migration vers l'ouest du relief nourricier. On attribue ceci à un cisaillement dextre de la marge continentale nord-américaine par suite d'une collision entre Avalonia et le Promontoire du Saint-Laurent. Le résultat ultime d'un cisaillement dextre soutenu fut l'impact d'Avalonia sur le Promontoire de New York, ce qui engendra le prisme de Catskill. En revanche, les sédiments dévoniens de la Gaspésie méridionale sont confinés à des bassins intramontagneux plus restreints, avec un paléocourant moyen vers le sud. Les dépôts comprennent des alluvions proximales (formations de Lagarde, Pirate Cove et Fleurant) et des sédiments lacustres (Formation d'Escuminac).

A l'opposé du vaste prisme détritique dévonien, les sédiments carboniferes gaspésiens s'accumulèrent en majorité sur des cônes de déjection. On attribue ce type de dépôt à une tectonique de failles, principalement à un décrochement dextre le long du Couloir de Fundy lors du blocage de la marge interne d'Avalonia sur le Promontoire de New York. Cependant, la Gaspésie se trouvait en périphérie du site principal de décrochement lié au cisaillement carbonifêre; elle semble avoir subi surtout un jeu selon le rejet-pente.

[Traduit par le joumal] 


\section{INTRODUCTION}

Our understanding of ancient plate motions and orogenies has been based largely on tectonics and geophysics, notably paleomagnetism. However, the nature of uplifts at active continental margins is best deduced from terrestrial successions, notably alluvial strata. The volume and grain size of clastic rocks indicate the magnitude of ancient drainage systems and their source terranes. Paleocurrents show source location, and facies relationships reflect environmental changes, from which the evolution of the tectonic framework can be deduced.

The Gaspé Peninsula provides superb coastal exposures of Devonian and Carboniferous terrestrial clastics, resulting from the Acadian and Alleghenian orogenies, respectively. The midGaspé Devonian belt extends the length of the Gaspé Peninsula, but is well known only on the east coast, where Lower to Middle Devonian strata occur in unbroken sequence (Figs. 1,2). Lower, Middle and Upper Devonian clastic rocks are present on the southern Gaspé shore, in a less complete succession.

Mid-Carboniferous strata are exposed extensively on the eastern and southern Gaspé coast (Figs. 2, 3). They are similar to Carboniferous rocks elsewhere in Atlantic Canada, but differ in sedimentary style from the Devonian sequences, a reflection on differences between Acadian and Alleghenian deformation (Rust, 1981).

\section{THE DEVONIAN SUCCESSION OF EASTERN GASPE}

The Devonian rocks of eastern Gaspé comprise a $5 \mathrm{~km}$-thick coarsening-upward clastic wedge comprising the York River, Battery Point and Malbaie formations (Rust, 1984a; Lawrence, 1986). The wedge rests conformably on Lower Devonian plat- form carbonates of the Upper Gaspé Limestone Group (Bourque, 1977). Bourque et al. ( in press) showed that water depth on the platform gradually increased until terminated by rapid shallowing as the clastic wedge prograded into the area.

\section{The York River Formation}

The York River Formation, the lowest Devonian clastic unit in eastern Gaspé (Fig. 4), varies in thickness from $1.6 \mathrm{~km}$ in southern outcrops to less than $200 \mathrm{~m}$ on the north shore of Gaspe Bay (Brisebois, 1981). The lower strata contain brachiopods, bivalves and gastropods, dated as Late Siegenian to Early Emsian (McGerrigle, 1950; Boucot et al., 1967). This marine fauna becomes sparse towards the top of the formation, but spores have yielded similar dates (McGregor, 1973, 1977).

On the east coast the York River Formation coarsens upwards from a mudstone-siltstone-sandstone assemblage to a sandstone-dominated succession. This sequence resulted from progradation of small fluvially-dominated delta distributaries into interdistributary bays or lagoons (Lawrence, 1986). Paleocurrent data indicate axial drainage towards the WNW (Fig. 5a), a trend also evident in York River outcrops in central Gaspé (Poole et al., 1970). This indication of a western marine connection is supported by open marine faunas of Early and Middle Devonian age in Mesozoic diatreme breccia near Montreal (Boucot et al., 1986).

\section{The Battery Point Formation}

The Battery Point Formation is about $2.5 \mathrm{~km}$ thick in eastern Gaspé, overlying the York River Formation conformably (Brisebois, 1981). Locally, limited intervals in the lower Battery Point

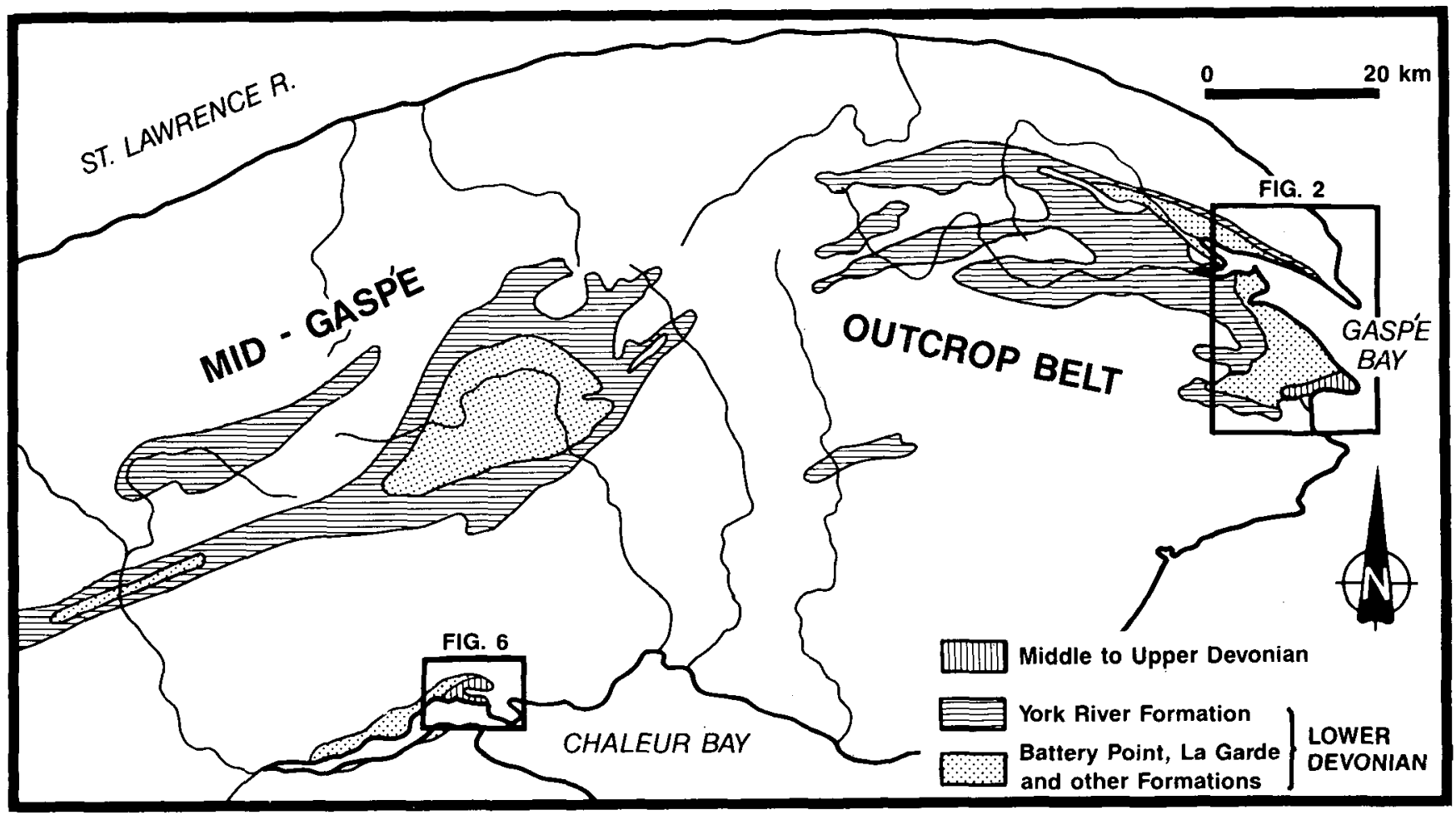

Fig. 1. Distribution of Devonian clastic rocks in Gaspé Peninsula (after Lawrence, 1986). 


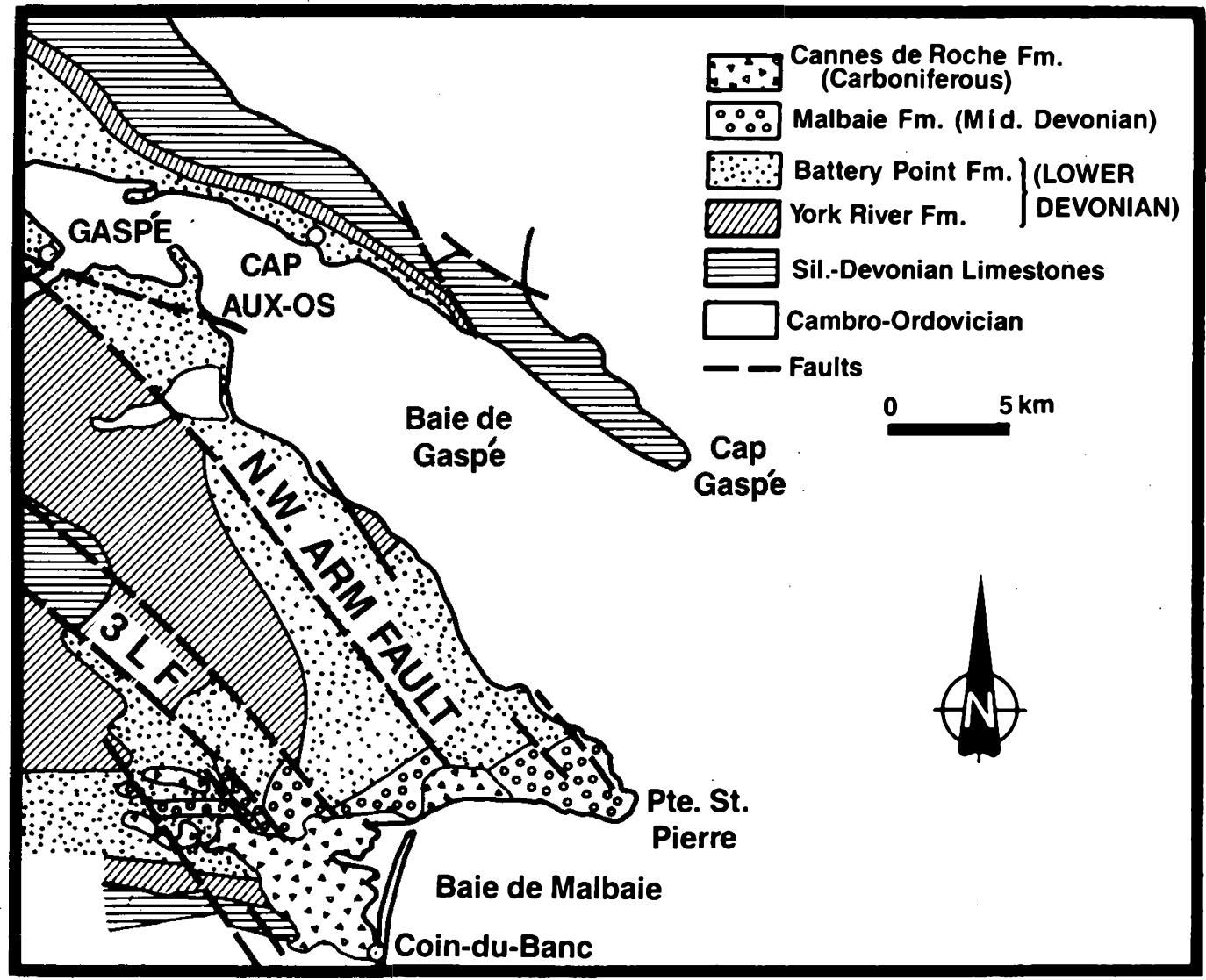

Fig. 2. Geological map of eastem Gaspé (after Brisebois, 1981).

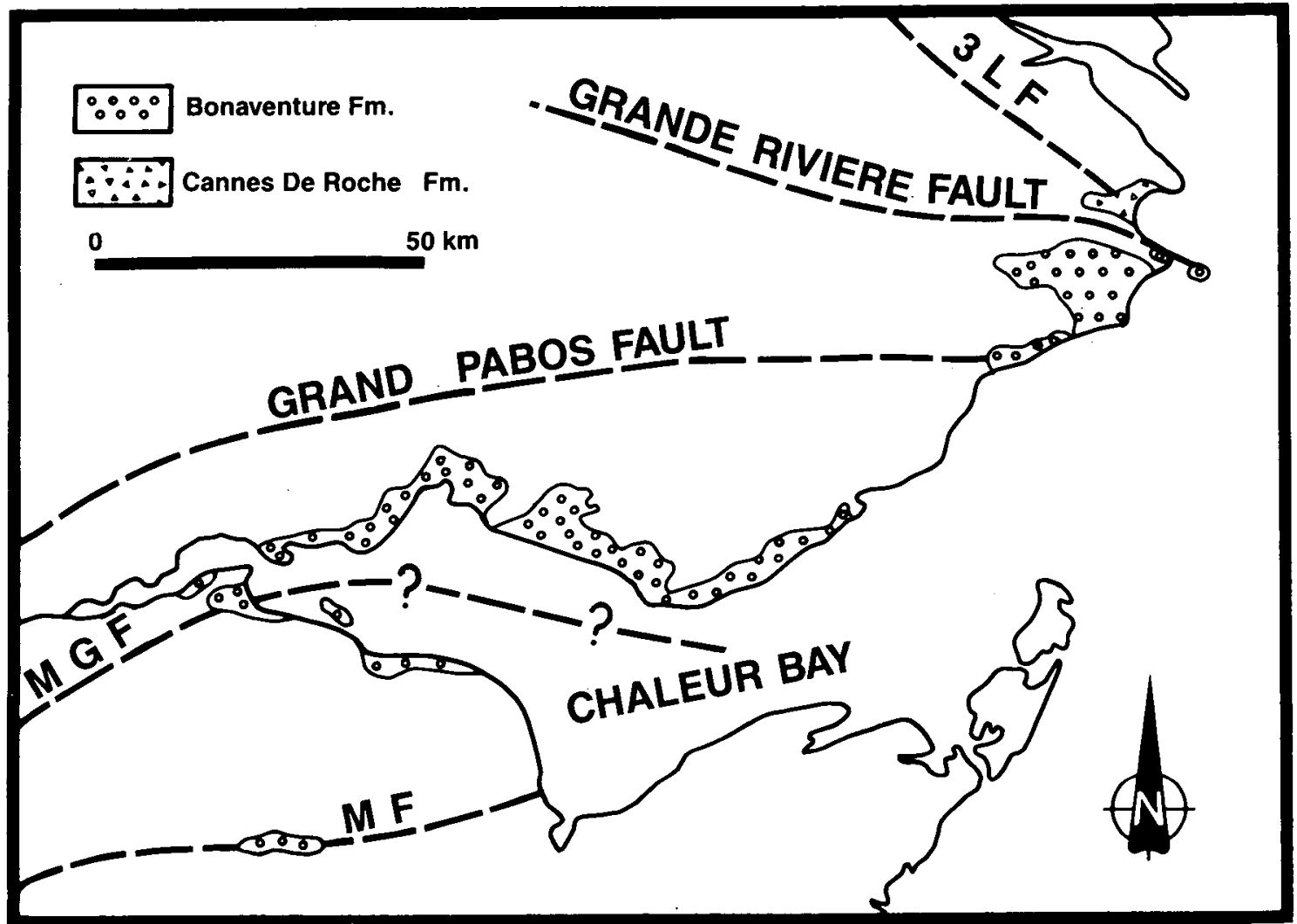

Fig. 3. Distribution of Carboniferous rocks in Gaspé and northem New Brunswick. 3 LF - Third Lake Fault, MGF - McKenzie Gulch Fault, MF Millstream Fault. 


\begin{tabular}{|c|c|c|c|c|c|}
\hline & & NY W & NYE & GASPE S & GASPE E \\
\hline \multicolumn{2}{|c|}{ CARBONIFEROUS } & $\begin{array}{l}\text { OLEAN } \\
\text { CGL }\end{array}$ & & $\begin{array}{l}\text { BONAVENTURE } \\
\text { FM }\end{array}$ & $\begin{array}{l}\text { CANNES-DE- } \\
\text { ROCHE FM }\end{array}$ \\
\hline \multirow{5}{*}{$\begin{array}{l}\frac{\pi}{4} \\
\frac{a}{0}\end{array}$} & \multirow{2}{*}{$\frac{2}{\sum_{W}^{\infty}}$} & $\begin{array}{c}\text { CONEWANGO } \\
\text { GP }\end{array}$ & & & \\
\hline & & $\begin{array}{c}\text { CANADAWAY } \\
\text { GP }\end{array}$ & & & \\
\hline & \multirow{3}{*}{ 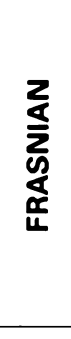 } & $\begin{array}{c}\text { WEST FALLS } \\
\text { GP }\end{array}$ & & & \\
\hline & & $\begin{array}{c}\text { SONYEA } \\
\text { GP }\end{array}$ & & $\begin{array}{c}\text { ESCUMINAC } \\
\text { FM }\end{array}$ & \\
\hline & & $\begin{array}{c}\text { GENESEE } \\
\text { GP }\end{array}$ & & FLEURANT & \\
\hline \multirow{5}{*}{ 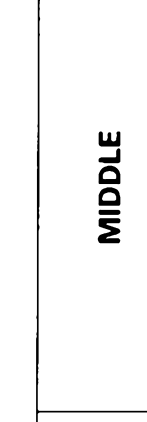 } & \multirow{2}{*}{$\sum_{0}^{2}$} & TULLY FM & & & \\
\hline & & $\begin{array}{c}\text { HAMILTON } \\
\text { GP }\end{array}$ & $\begin{array}{l}\text { SKUNNEMUNK } \\
\text { CGL }\end{array}$ & & \\
\hline & \multirow{3}{*}{$\frac{z}{\frac{z}{4}}$} & MARCELLUUS & BELLVALE SS & & \\
\hline & & ONONARACA & CORNWALL SH & PIRATE & \\
\hline & & UNONDAGA & EDGECLIFF LS & COVE FM & MALBAIE FM \\
\hline \multirow{4}{*}{ 䍃 } & \multirow{2}{*}{$\begin{array}{l}z \\
\sum_{W}^{\infty} \\
\text { D }\end{array}$} & & & \multirow{3}{*}{$\begin{array}{c}\text { LAGARDE } \\
\text { FM } \\
? \\
?\end{array}$} & $\begin{array}{l}\text { BATTERY } \\
\text { POINT FM }\end{array}$ \\
\hline & & & & & $\begin{array}{c}\text { YORK RIVER } \\
\text { FM }\end{array}$ \\
\hline & 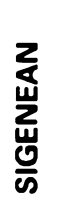 & & & & $\begin{array}{c}\text { UPPER } \\
\text { GASPE } \\
\text { LS GROUP }\end{array}$ \\
\hline & 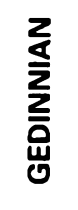 & & & ----- & $\begin{array}{l}\text { CHALEURS } \\
\text { GROUP }\end{array}$ \\
\hline \multicolumn{2}{|c|}{ SILURIAN } & & & VOLCANICS & \\
\hline
\end{tabular}

Fig. 4. Correlation diagram for Devonian units in Gaspé and New York (after Sevon, 1985).

contain a few brachiopods and bivalves (McGerrigle, 1950), indicating a marine connection. The marine fauna is absent from other parts of the formation, which have typically alluvial facies assemblages (Lawrence, 1986). Spores obtained from through- out the formation date it as early Emsian to early Eifelian (Fig. 4), (McGregor, 1973, 1977).

The Petit-Gaspé Member, the lowermost Battery Point unit, is attributed to deposition in perennial sandy braided rivers (Cant 

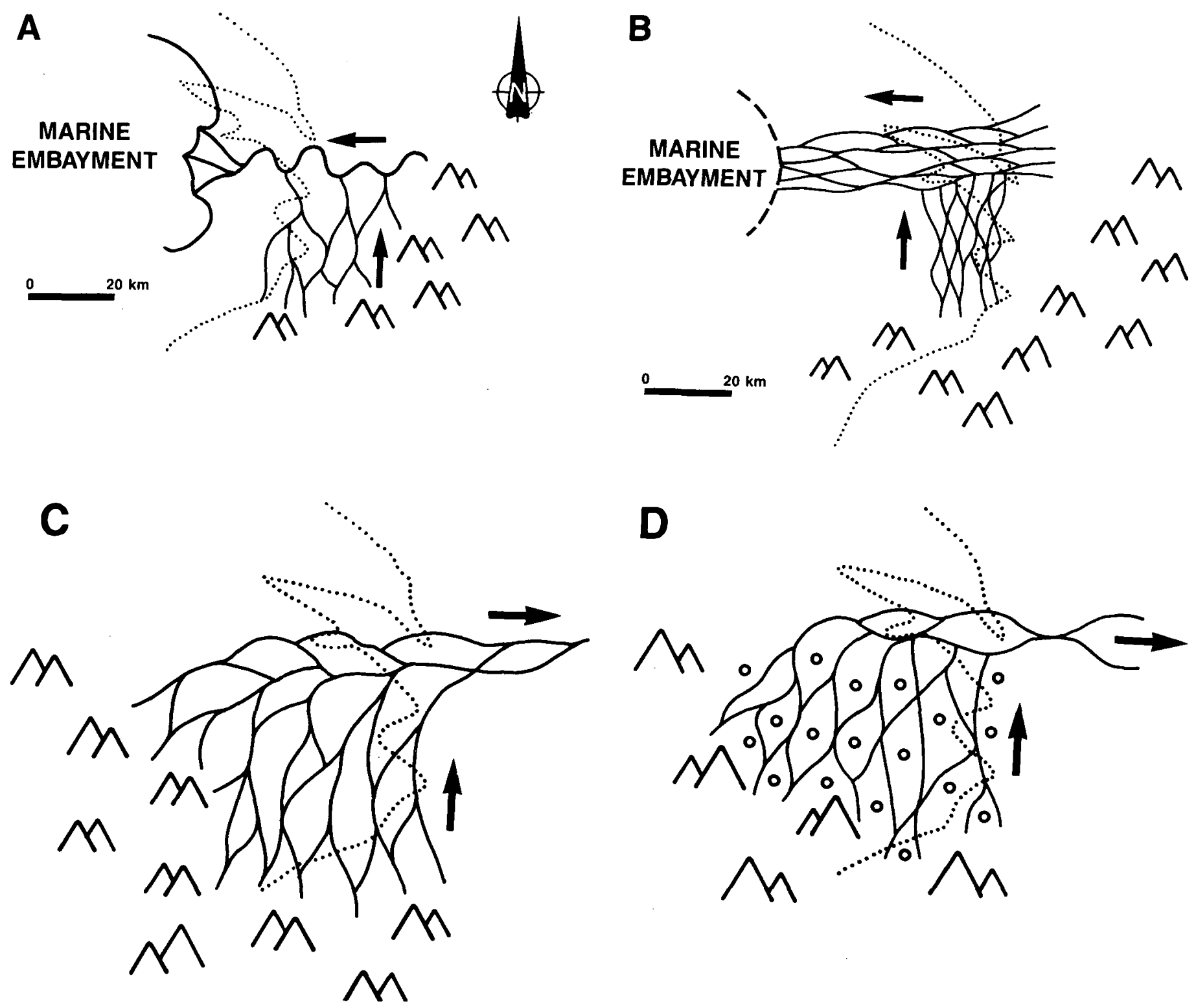

Fig. 5. Paleogeography of (A) York River Formation (Cap-aux-Os Member, Battery Point Formation was similar), (B) Petit-Gaspé Member, Battery Point Formation, (C) Fort Prével Member, Battery Point Formation, (D) Malbaie Formation.

and Walker, 1976; Lawrence, 1986). Paleocurrents directed WNW on the north shore of Gaspe Bay and northward on the south shore indicate a west-flowing axial system at the foot of a north-sloping alluvial plain (Fig. 5b). The overlying Cap-auxOs Member on the north shore of Gaspé Bay comprises sandstone and mudstone sequences interbedded on a scale of $5 \mathrm{~m}$ to several tens of meters. Parts of the sequence are interpreted as distal alluvium with moderate to high sinuosity channels; other parts as tidally influenced coastal plain deposits, with a marginal marine fauna (Pageau and Prichonnet, 1976). Paleocurrents indicate that westward to northwestward axial flow was maintained, but sediment continued to come mainly from the south.

The upper Battery Point Formation (Fort Prével Member) conformably overlies the lower Battery Point, and passes up conformably into the Malbaie Formation (Rust, 1976). The Fort Prével shows domination by sheetflood deposition on a sandy braidplain, locally pebbly (Lawrence and Williams, 1987).
Paleoflow came from uplands to the south, with axial drainage towards the ESE, a $180^{\circ}$ reversal relative to the lower Battery Point Formation (Fig. 5c).

\section{The Malbaie Formation}

The apparently conformable contact between the Battery Point and Malbaie Formations is marked by the first major unit of extraformational cobble to small boulder conglomerate in the clastic wedge. The Malbaie Formation is about $1450 \mathrm{~m}$ thick (Rust, 1976) and progressively coarsens upwards as conglomerate abundance increases, although mean particle size of the conglomerate does not change upwards (Rust, 1984a). An early to mid Eifelian age is based on spores (McGregor, 1973, 1977).

The conglomerate and sandstone units of the Malbaie Formation show abrupt alternation, and are attributed to deposition on proximal braidplains (Rust, 1984a). The conglomerates are 
predominately horizontally stratified and imbricate, with minor planar cross strata, a facies assemblage characteristic of proximal gravelly braided rivers (Rust, 1978) and proximal Icelandic outwash plains (Boothroyd and Nummedal, 1978). The lateral extent and uniformity of the conglomerate assemblage indicates deposition on a braidplain rather than a valleyconfined river (Rust and Koster, 1984).

The sandstone units of the Malbaie Formation contain abundant erosion surfaces and intraformational mudclast conglomerate. Trough cross-stratified sandstone and horizontal to lowangle stratified sandstone are common facies, completing an assemblage attributed to deposition on a proximal sandy braidplain (Rust, 1984a). Paleocurrents for the sandy braidplain are northward, whereas those for the gravelly braidplain trend eastward (Fig. 5d). This pattern continues that of the underlying upper Battery Point Formation, namely a northward paleoslope, with eastward axial drainage.

\section{DEVONIAN STRATA IN SOUTHERN GASPE}

The Devonian strata in southem Gaspé are interrupted by breaks, and comprise the following formations: Lagarde (Lower or Middle Devonian), Pirate Cove (Middle Devonian), Fleurant and Escuminac (Upper Devonian, Figs. 4, 6).

Dineley and Williams (1968) reported the Lagarde Formation to be unconformable on volcanic rocks of the SiluroDevonian Dalhousie Group (Ristigouche Volcanics in Gaspé). However, recent work by C. Gamba shows that the base of the Lagarde sequence is conformable with the uppermost Dalhousie Group volcanics in northern New Brunswick. This evidence questions the dates in the Gaspé South column of Figure 4, and will be investigated further by Gamba. The volcanic rocks are mainly andesites, but range from basalts to rhyolites (Laurent and Bélanger, 1984). Some flows are pillowed, indicating subaqueous extrusion, but exclusively volcaniclastic conglomerates interbedded with volcanic flows in the lower part of the Lagarde Formation suggest subaerial deposition. The volcanic clasts are well-rounded boulders, indicating energetic fluvial systems, and implying that the volcanoes had considerable terrestrial relief.

\section{The Lagarde Formation}

Dineley and Williams (1968, Table 1) placed the Lagarde Formation in the Lower or Middle Devonian, whereas Bourque et al. (in press) regard it as late Emsian. It largely comprises grey to green boulder to pebble conglomerate, with minor sandstone and mudrocks. The conglomerate clasts are mainly lavas, with minor intrusives, quartz and quartzite, and locally a few limestone clasts. The sedimentology of this formation, under investigation by C. Gamba (M.Sc., University of Ottawa), indicates deposition mainly as proximal alluvium.

\section{The Pirate Cove Formation}

Dineley and Williams (1968) interpreted the poorly exposed contact between the Lagarde and overlying Pirate Cove formations as conformable. However, the Pirate Cove mainly com- prises red limestone conglomerate (Zaitlin, 1981, Fig. 13), a contrast with the Lagarde which implies changes in provenance and paleoclimate that suggest a break between the two formations. Dineley and Williams $(1968$, p. 949$)$ reported that the two formations have similar spore content, which implies that the break was of minor duration, although probably accompanied by tectonic modification of paleodrainage.

Dineley and Williams (1968) regarded the Pirate Cove Formation as Lower or Middle Devonian, and Bourque et al. (in press) indicate its age as Eifelian (Middle Devonian). It is interpreted as an alluvial deposit on the basis of its facies assemblages and the abundance of in situ roots (Zaitlin, 1981). It comprises alternating units of conglomerate and mudrock assemblages, with little sandstone in either.

The conglomerate units are dominated by horizontally stratified pebble to cobble conglomerate, with minor tabular units of planar cross-stratified pebble conglomerate. In marked contrast, the mudrock units predominantly comprise mudstone and rippled siltstone, with abundant in situ roots. Very fine sandstone forms about $10 \%$ of the mudrock assemblage, and is predominantly rippled. The larger sandstone units form channel fills up to 1.8 $\mathrm{m}$ thick, which commonly fine upwards and display inclined heterolithic stratification (Thomas et al., 1987).

The marked contrast between the conglomerate and mudrock facies assemblages suggests that they were formed by separate alluvial systems. The most feasible model features a lateral alluvial fan-braidplain system and an axial muddy alluvial plain. Paleocurrents (principally clast imbrication) indicate that the conglomerate units were transported by southeastward flow, to which the axial system presumably was perpendicular, i.e., northeast-southwest. The nature of the channel fills indicates that the muddy axial alluvial plain was traversed by small meandering channels.

\section{The Fleurant Formation}

The Fleurant Formation is about $18 \mathrm{~m}$ thick, and overlies the Pirate Cove Formation with angular unconformity. It was dated as Late Devonian by Dineley and Williams (1968) and early Frasnian by Bourque et al. (in press). It mainly comprises wellrounded, horizontally stratified pebble to cobble conglomerate, with isolated individual and grouped boulders reaching $1.2 \mathrm{~m}$ in maximum diameter (Zaitlin, 1981). Minor lenses of planar crossstratified conglomerate are finer grained and transitional into planar or trough cross-stratified sandstone. Thinly laminated siltstone or shale is a minor component.

The facies assemblage outlined above is characteristic of proximal braidplain or braided river deposits. There is no evidence for confinement within a paleovalley, so the former interpretation is favoured. It is the same as the interpretation for conglomerate units in the Malbaie Formation, which closely resemble the Fleurant Formation. Zaitlin (1981) showed that the transport direction based on conglomerates imbrication was southeastward, and that clast composition averages $20 \%$ volcanics, $5 \%$ plutonic rocks, with the rest sedimentary, principally limestones. This suggests a provenance similar to that of the Pirate Cove Formation: mainly Lower Paleozoic sedimentary 


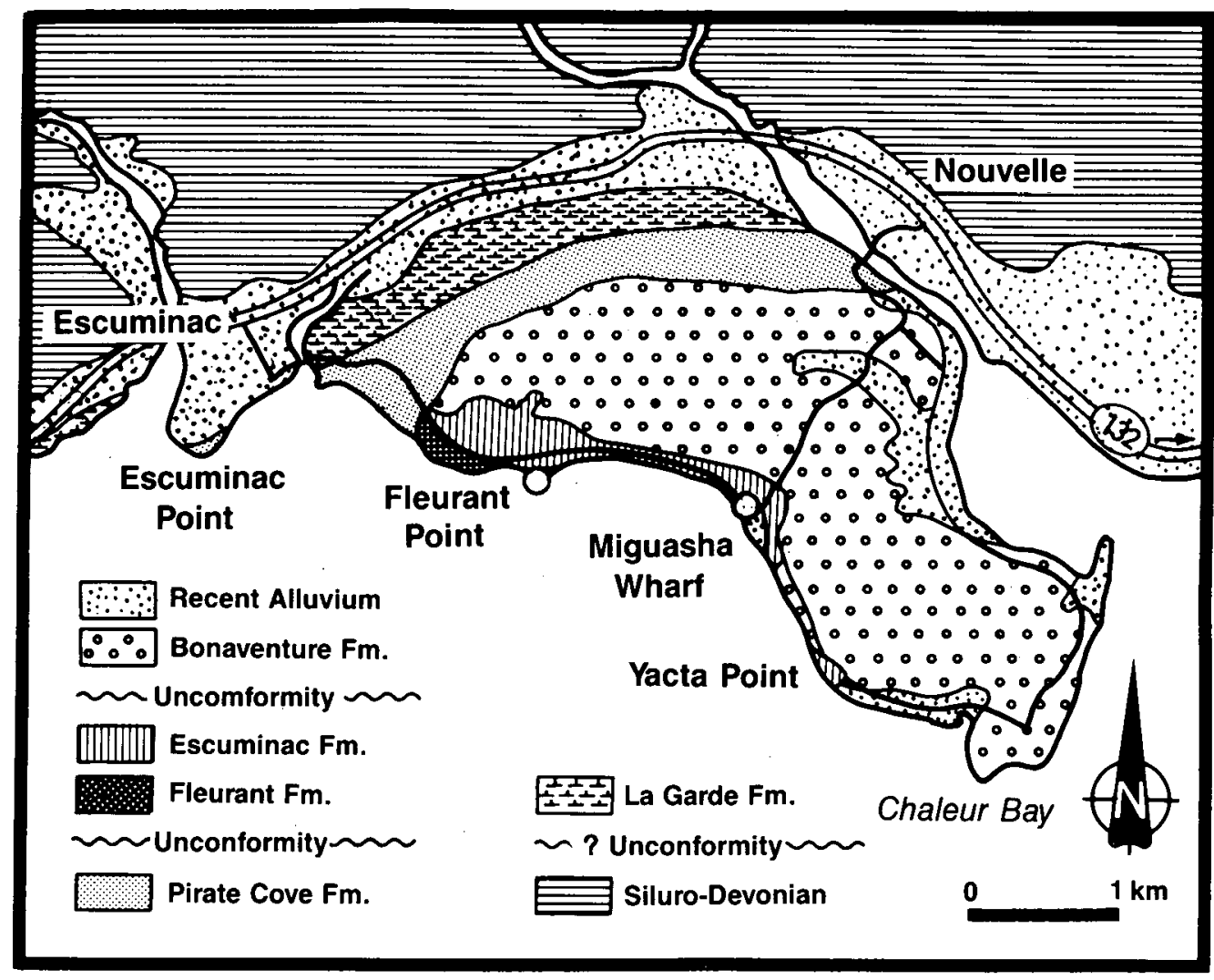

Fig. 6. Geological map of Miguasha area, Chaleur Bay, Quebec (after Dineley and Williams, 1968). Main outcrop area of Lagarde Formation is to the east, but has not been studied in detail.

rocks of the Matapedia Group (Bourque et al., in press).

\section{The Escuminac Formation}

The Escuminac Formation conformably overlies the Fleurant Formation, although Zaitlin (1981) noted abrupt change from fluvial conglomerates in the Fleurant to turbidites in the Escuminac Formation. This indicates a marked environmental change from subaerial to basinal subaqueous conditions, without the intervention of shallow-water facies, suggesting at least a minor temporal break. Zaitlin (1981) therefore regarded the Fleurant-Escuminac contact as a disconformity. The Escuminac Formation contains abundant vertebrates, indicating a Late Devonian (Frasnian) age (Orvig, 1957).

The $118 \mathrm{~m}$-thick Escuminac Formation comprises an alternation of rhythmically laminated grey-green mudrocks and graded siltstones to sandstones. Sedimentary structures in the graded units are consistent with turbidites: flutes, grooves and other sole structures; ripple cross-lamination, horizontal stratification, and slump structures. Paleocurrents indicate that turbidity currents flowed consistently towards the southwest (Hesse and Sawh, 1982, Fig. 1-5).

Most authors have interpreted the Escuminac Formation as lacustrine (Dineley and Williams, 1968; Hesse and Sawh, 1982), based on association with other continental deposits (notably the Fleurant Formation), and on the abundant fauna and flora. However, Schultze and Arsenault (1985) pointed out that many faunal elements have been described from fresh, brackish and marine environments, but the lack of undoubted marine biota favours a lake. The inferred intermontane setting (discussed below) is also more compatible with lacustrine origin.

\section{Correlation of Devonian Units}

Dineley and Williams (1968, Table 1) suggested correlation between the Battery Point and Lagarde Formations, and between the Malbaie and Pirate Cove Formations (Fig. 4). The Battery Point and Lagarde Formations are probably similar in age, have similar lithologies and are both predominantly alluvial. However, there is no evidence for marine strata in the Lagarde Formation. There are also similarities between the probable ages and the lithologies of the Malbaie and Pirate Cove Formations. However, the Malbaie was deposited on a broad braidplain, whereas Pirate Cove deposition was locally influenced by alluvial fan accumulation. The Fleurant and Escuminac Formations do not have equivalents in eastern Gaspé, and there are paleogeographic differences between the eastern and southern successions. The clastic wedge in the east had a consistent northward paleoslope, attributed to the uplift of Acadian mountains to the south. Paleocurrents of the southern Gaspé successions are variable: southeastward for the Pirate Cove and Fleurant Formations, southwestward for the Escuminac Formation. This variability and northern provenance suggest accumulation in intermontane basins within the Acadian mountain belt. 
The Devonian clastic wedge of eastern Gaspé more closely resembles the Catskill wedge of New York and adjacent areas. This wedge also contains marine strata at lower levels, and coarsens upwards to progressively more proximal alluvial strata. The distribution and dispersal pattern (Sevon, 1985, Figs. 1, 2) indicate transport of sediment away from the rising Acadian mountains. The only major difference between the two successions is that the Catskill wedge is younger, extending to the uppermost Devonian (Fig. 4).

\section{THE CARBONIFEROUS SUCCESSIONS OF SOUTHERN AND EASTERN GASPE}

Carboniferous rocks occur along the Gaspé and New Brunswick coasts of Chaleur Bay and in Malbaie Bay (Fig. 3). The latter exposures comprise the Cannes de Roche Formation, which contains plants and spores. Hacquebard (1972, Table IV, Fig. 6) indicated an Early Namurian age, but M.S. Barss (in Rust, 1984b) suggested a Viséan affinity. The Carboniferous rocks along the Chaleur Bay coasts comprise the Bonaventure Formation. They have not yielded spores, but are correlated with the Cannes de Roche on the basis of proximity and lithological similarity.

\section{The Cannes de Roche Formation}

The Cannes de Roche Formation comprises three members: a lower red breccia or conglomerate, a middle red mudstone, and an upper grey to buff conglomerate and sandstone with minor mudstone (Rust, 1984b). It rests with angular discordance on the
Middle Devonian Malbaie (Rust, 1976) and older formations.

The Lower Member of the Cannes de Roche Formation is interpreted as an alluvial fan deposit (Fig. 7), based mainly on the presence of matrix-supported breccias with fabrics typical of viscous debris flows (Rust, 1984b). Other coarse-grained strata are predominantly water-lain and alternate with sandstones and sandy mudstones in fining-upward sequences, interpreted as flood deposits. The finer sediments contain abundant pedogenic calcretes.

The Lower Member is transitional upward into the Middle Member, in which red mudstone is predominant. Pedogenic calcretes are also present, as are minor breccia or conglomerate units, interpreted as distal flood deposits on a muddy braidplain formed by distal coalescence of the Lower Member fans (Fig. 7).

The Upper Member of the Cannes de Roche Formation mainly comprises grey to buff sandstones and conglomerates, with minor grey mudstone in repetitive fining-upward sequences dominated by trough cross-stratified conglomerate in sets up to $2 \mathrm{~m}$ thick. The magnitude of these sets indicates formation in deep perennial channels, and the fining-upward sequences are interpreted as channel-fills of a braided river (Rust, 1984b). Paleocurrent directions are perpendicular to those of the alluvial fans in the Lower Member, indicating that the Upper Member was formed in a trunk river bounded by tributary alluvial fans and their distal braidplain equivalent (Fig. 7).

\section{The Bonaventure Formation}

The sedimentology of the Bonaventure Formation has been studied only in western Chaleur Bay (Zaitlin, 1981; Zaitlin and

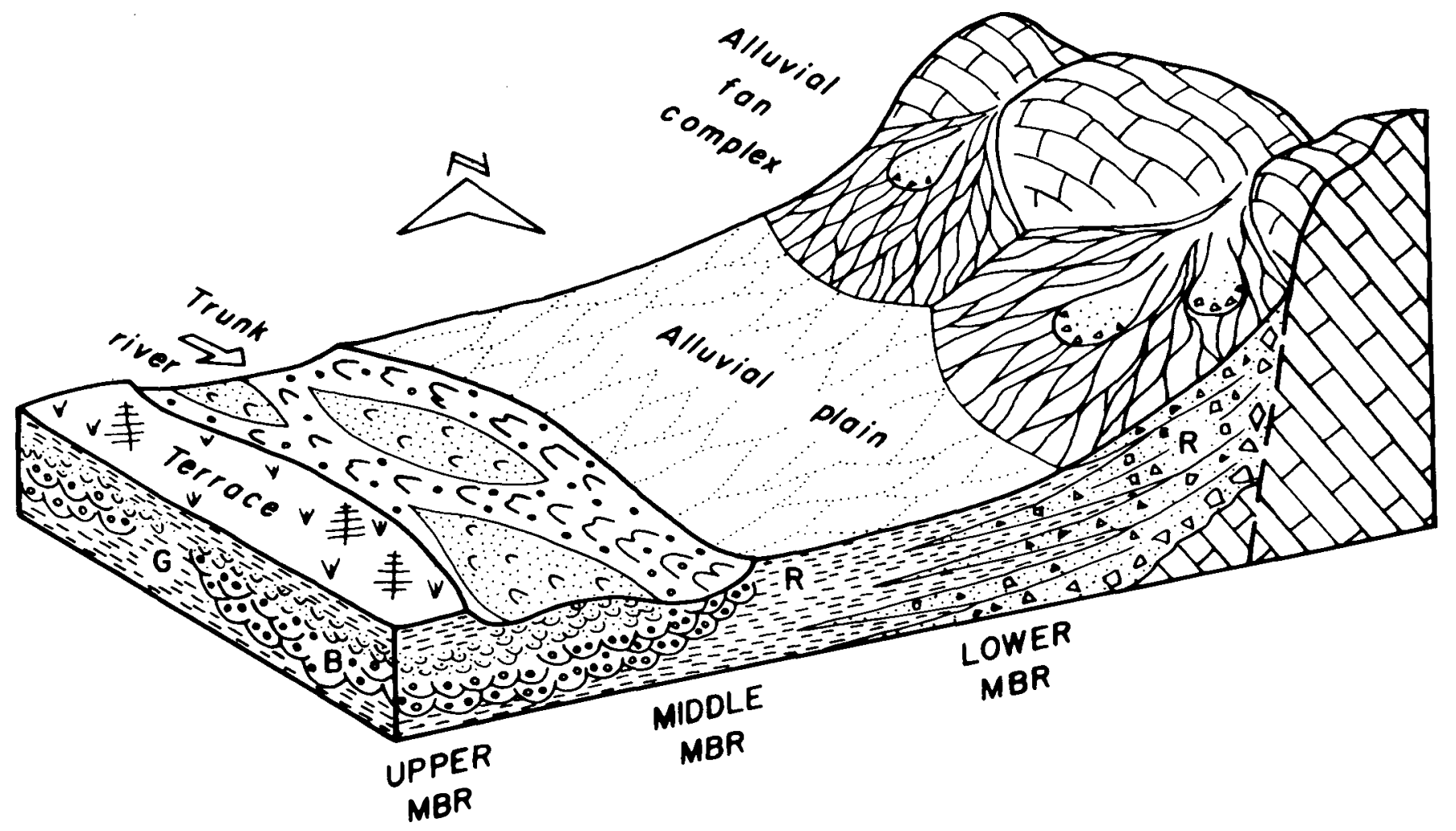

Fig. 7. Depositional model for Cannes de Roche Formation. R - red, B - buff, G - grey-green. 
Rust, 1983). The thickest section is at Yacta Point (Fig. 6), where the Bonaventure rests discordantly on the Escuminac Formation. The lowermost Bonaventure strata contain slightly displaced slabs of Escuminac sandstone up to $1.3 \mathrm{~m}$ long and are interpreted as talus deposits. They are transitional upwards into largely massive conglomerate, the major component of two $25 \mathrm{~m}$ finingupward sequences attributed to proximal alluvial fan deposition.

The middle part of the Yacta Point succession contains 1-25 $\mathrm{m}$ fining-upward sequences of intraclastic conglomerate, horizontally-stratified sandstone and mudstone. The sequences are interpreted as flood deposits of distal alluvial fans on which nodular calcretes indicate incipient soil formation, as in the Cannes de Roche Formation. The top of the succession is predominantly mudstone, with minor horizontally-stratified sheet sandstones, probably a braidplain deposit, analogous to the Middle Member of the Cannes de Roche Formation. A notable feature is the presence of conglomerate-filled channels averaging $1.5 \mathrm{~m}$ deep and 3 to $5 \mathrm{~m}$ wide. They are attributed to incision due to uplift in source areas or lowering of the basin. The fill in the channels is coarser higher in the sequence, which suggests that rejuvenation was taking place, probably along faults with dipslip displacement.

Paleocurrents in the western Chaleur Bay area, based mainly on conglomerate imbrication show south to southeastward flow from northern outcrops and north to northeastward from the New Brunswick sections. This suggests that Chaleur Bay was a Carboniferous paleovalley fringed by mountains shedding debris to alluvial fans, which were transitional distally to a braidplain draining eastward (Fig. 8).

\section{TECTONIC SIGNIFICANCE OF THE DEVONIAN AND CARBONIFEROUS SUCCESSIONS IN GASPE}

\section{Acadian Orogeny}

The Devonian clastic wedge in eastem Gaspé is $5 \mathrm{~km}$ thick and extends at least $200 \mathrm{~km}$ along the mountain belt. Its upward coarsening character and consistent northward paleoslope is attributed to a major mountain belt rising to the south. Deepening of the Lower Devonian carbonate platform prior to wedge progradation is attributed to formation of a complementary foreland basin in response to isostatic loading. Upward facies change in the clastic wedge reflects paleoenvironmental evolution from shallow shelf (York River Formation) to coastal plain/ distal alluvial plain (lower Battery Point Formation) to medial to proximal braidplain (upper Battery Point, Malbaie formations). The switch in axial paleodrainage from westward for the York River and Lower Battery Point formations to eastward for the Upper Battery Point and Malbaie formations is attributed to westward migration of orogenesis and the maximum elevation within the mountain belt. This is consistent with the younger age of the equivalent clastic wedge in New York.

McKerrow and Cocks (1977), Schenck (1978) and McCutcheon and Robinson (1987) attributed Acadian deformation to closing of an eastern ocean during Silurian and Early Devonian times by subduction along the North American margin and collision with another continental terrane. The most likely terrane is Avalonia (Bradley, 1983) or a composite of Avalonia and other continental fragments (Keppie, 1985), which, on paleo-

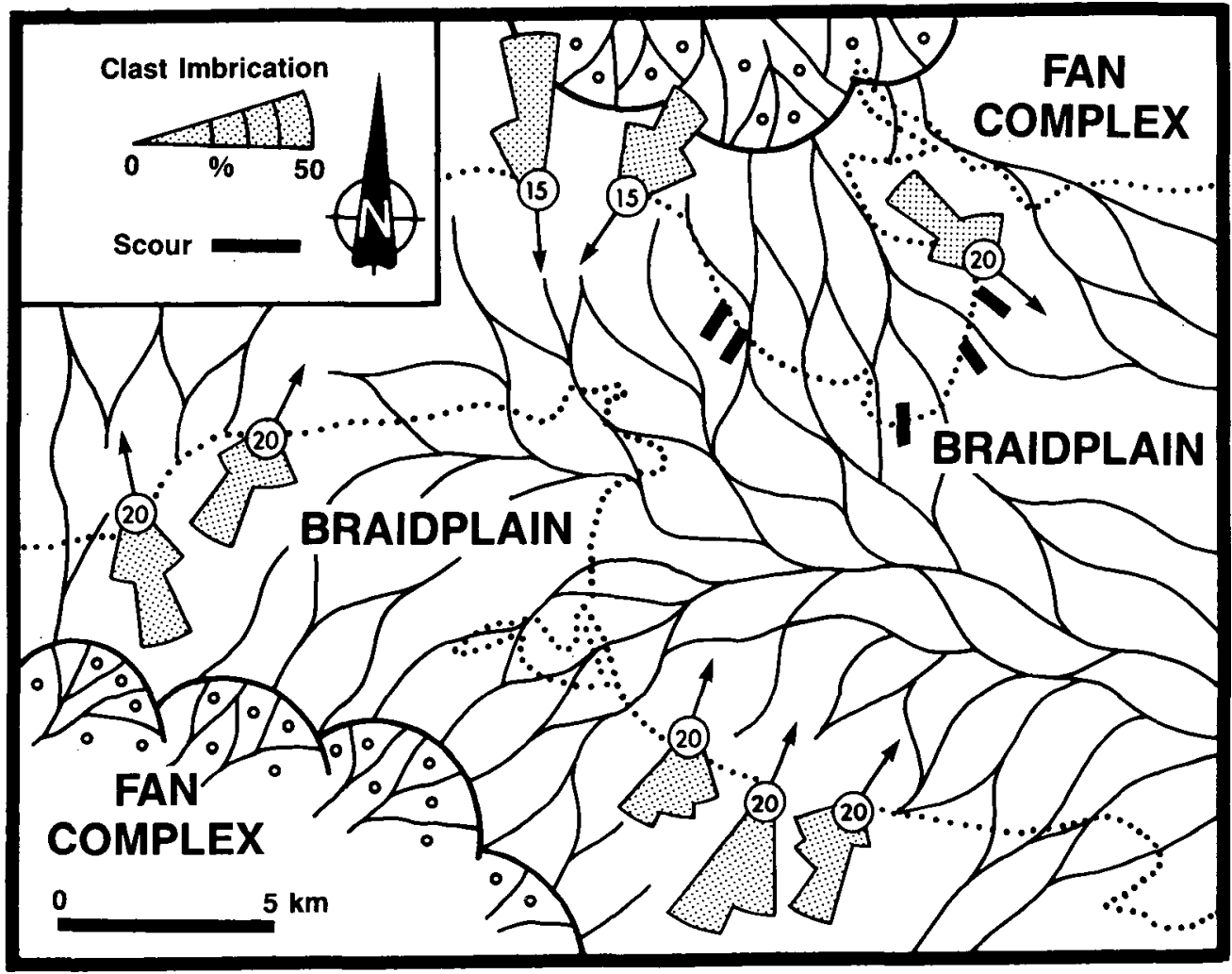

Fig. 8. Paleogeography of Bonaventure Formation in western Chaleur Bay region. 
magnetic evidence moved from southerly latitudes, but along an unknown path (Irving and Strong, 1985). Williams (1979) rejected the hypothesis of Acadian oceanic closure because of the lack of ophiolite (obducted oceanic lithosphere) in the Acadian Orogen. However, Moores (1982) and Casey and Savci (1988) showed that oceanic lithosphere is obducted only when young and relatively hot.

Williams and Hatcher (1982) proposed oblique convergence or strike-slip faulting as alternative explanations for Acadian deformation. Strike-slip faults can generate adjacent folds, but they are oblique to the faults (Christie-Blick and Biddle, 1985, Fig. 3). Acadian folds are regional in extent, and, excepting Gaspé, are parallel rather than oblique to major faults. In addition, strike-slip faulting cannot explain the extensive clastic wedges of eastern Gaspé or the Catskill region, with paleoslopes perpendicular to the orogen.

We conclude that Acadian deformation necessitates convergence, commencing at the St. Lawrence Promontory (Fig. 9a), and thence progressing along the Quebec Reentrant (Fig. 9b). Stockmal et al. (1987) suggested that essentially orthogonal collision between an outboard terrane and the promontory caused lithospheric delamination and tectonic wedging between Gaspé and Newfoundland, resulting in dextral shear along this line. Deformation progressed laterally along the orogen by dextral shear, combined with later arrival of more westerly parts of the outboard terrane (probably Avalonia), still moving along its original trajectory, similar to the lateral shearing of India as it collided with Asia (Tapponier et al., 1986). As a result, the midGaspé clastic wedge developed progressively, undergoing changes in paleodrainage as the location of maximum source elevation migrated westward. Intermontane basins opened in southern Gaspé, probably in local tensional settings, and accommodated the alluvial and lacustrine deposits of the Lagarde, Pirate Cove, Fleurant and Escuminac formations.

Ultimately, the southwestward migration of the convergence zone with Avalonia led to impact with the New York Promontory, raising mountains there, and shedding the Catskill wedge westward (Fig. 9c). Hence the proposed motion explains the diachronous progression of deformation along the Acadian belt, and the paleogeography of the Gaspé and Catskill clastic wedges.

\section{Alleghenian Orogeny}

The change in sedimentary style in Gaspe from the broad Devonian clastic wedge to alluvial fan deposits in the Carboniferous can be explained by a change in tectonism from convergence to faulting, chiefly strike-slip (Rust, 1981). Slip took place along many faults, but appears to have been mainly along the Fundy Rift Zone (Fig. 9d). We suggest that this zone was initiated or reactivated as an Acadian fracture as the inboard part of Avalonia locked with the New York Promontory (Fig. 9d), but was reactivated as an Alleghenian shear zone by later plate motions.

The principal fault influencing Carboniferous sedimentation in Gaspé was probably the McKenzie Gulch Fault (Bourque et al., in press) and its postulated eastward extension (Fig. 3).
Bourque et al. (in press) proposed dextral strike-slip on this fault during Acadian deformation. However, some dip-slip component was necessary to accommodate Carboniferous sedimentation and account for the evidence of rejuvenation discussed previously.

The Cannes de Roche Formation is bounded at its southwest margin (Fig. 3) by a probable splay of the Third Lake Fault (Brisebois, 1981; D. Kirkwood, personal communication, 1988), a dextral Acadian shear according to Bourque et al. (in press). Displacement of Cannes de Roche strata is predominantly dipslip, and at some locations has a thrust component (Rust, 1984b).

Elsewhere in the Alleghenian Orogen there is abundant evidence of Carboniferous faulting in the form of adjacent alluvial fan deposits. These deposits range in age from the Late Devonian Perry Formation at the New Brunswick/Maine border (Schluger, 1973) to the Late Carboniferous Cumberland Group in northwest Nova Scotia (Salas, 1986). Many faults influenced Carboniferous sedimentation (Webb, 1969), but the timing and slip direction of many are unknown. According to Bradley (1983) strike-slip displacements are known for 12 of the faults, of which 11 are dextral. Most strike northeast parallel to the orogen, for instance the Cabot Fault and its splays in Newfoundland. Hyde (1984) concluded that this system experienced about 50-100 km dextral displacement during Namurian and Viséan times, but that later oblique- and dip-slip also occurred. Dextral displacement also characterises Alleghenian shear zones in the southern Appalachians, for example the Brevard zone (Vauchez, 1987).

Dextral slip has also been demonstrated on east-west faults of the Fundy system, for example Westphalian displacement on the Cobequid-Hollow fault system (Yeo and Gao, 1986), and the Cobequid Fault (Eisbacher, 1969). We conclude that the Alleghenian Orogeny in the northern Appalachians was dominated by fault tectonics, chiefly dextral strike-slip, with displacements up to several hundred kilometers. Oblique- and dip-slip occurred elsewhere, for example on the Belleisle Fault (McCutcheon and Robinson, 1987), probably as local responses to the overall transcurrent stress field (Christie-Blick and Biddle, 1985).

The faults controlling mid-Carboniferous alluvial sedimentation in Gaspé are attributed to predominantly dip-slip rejuvenation of earlier dextral faults. Renewed dextral displacement was insignificant because the main strike-slip deformation was located along the Fundy Rift Zone. The result in Gaspe was rejuvenation as grabens or half grabens without significant longitudinal displacement.

Keppie (1985) postulated that Alleghenian deformation resulted from collision between Gondwana and North America in the Late Carboniferous and Permian. We suggest that this reactivated existing faults, particularly the Fundy Rift Zone, and in addition caused deformation and metamorphism in more southerly parts of the Alleghenian belt. Hence Alleghenian deformation was in part a response to residual Acadian weaknesses.

\section{CONCLUSIONS}

(1) The mid-Devonian clastic wedge in eastern Gaspé is $5 \mathrm{~km}$ 
A
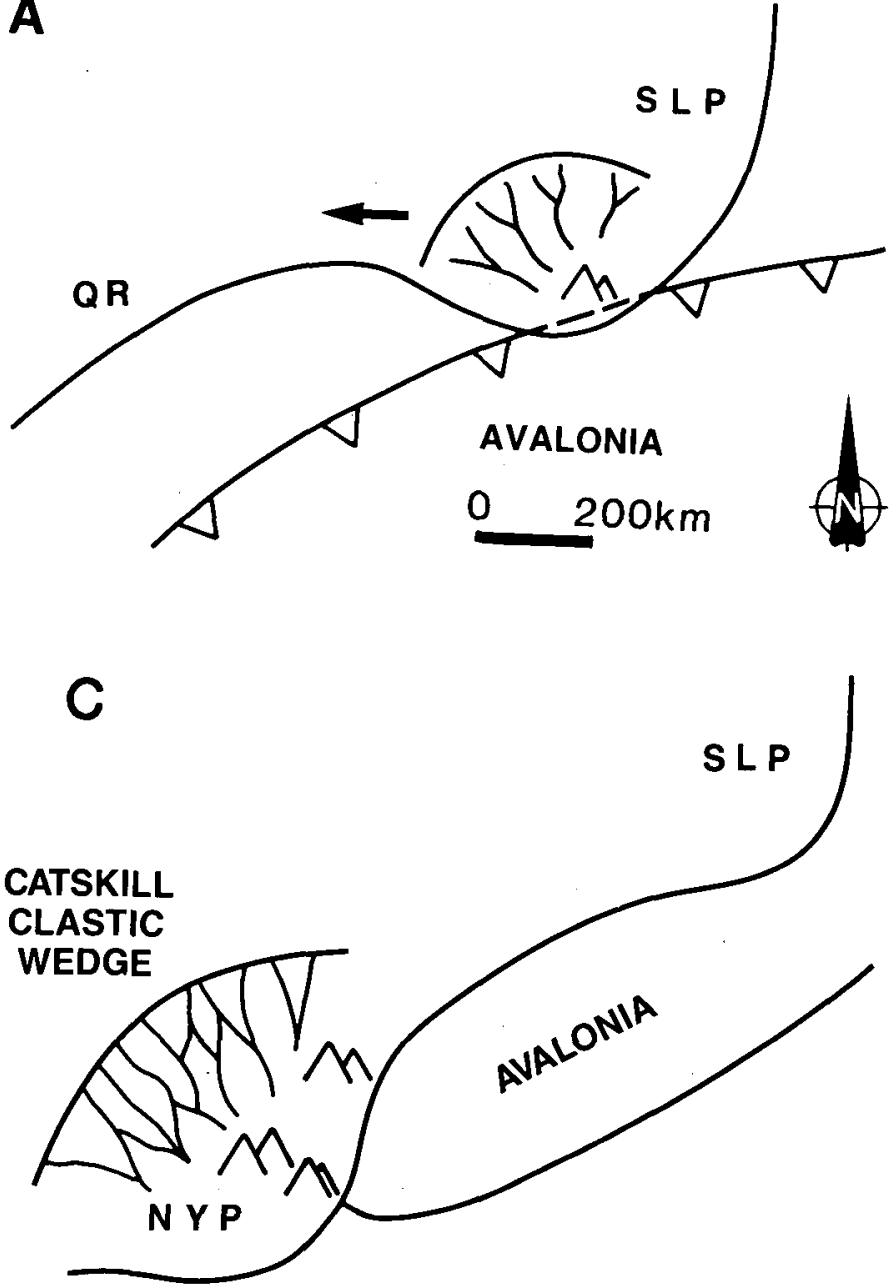

B
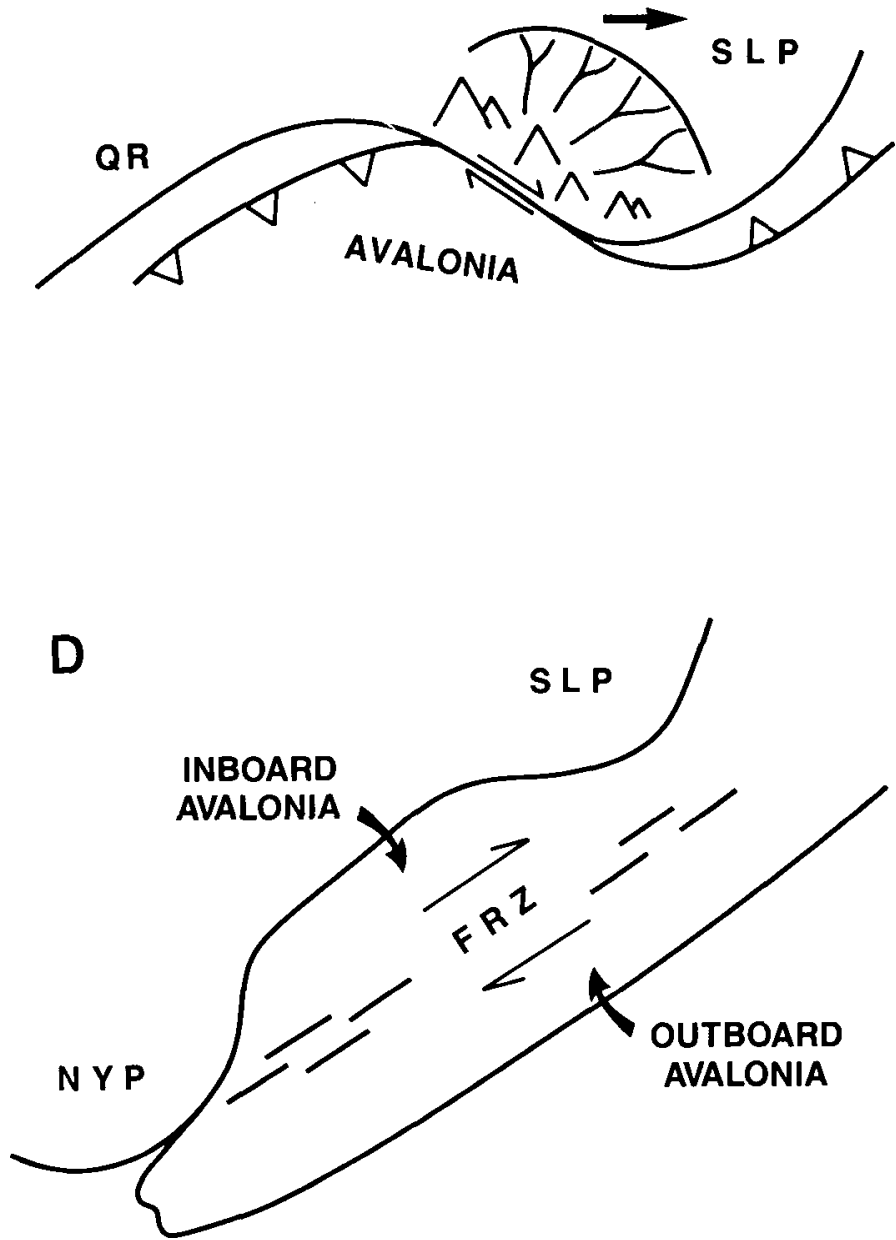

Fig. 9. Hypothetical tectonic models for Acadian and Alleghanian deformation along the North American continental margin. (A) Convergence between Avalonia (probably including additional elements of accreted terrane) and St. Lawrence Promontory (SLP) raises mountains and generates a major clastic wedge in eastern Gaspé. (B) Convergence results in dextral shearing in the Gaspé region of the Quebec Reentrant (QR) (after Stockmal et al., 1987). (C) Continued dextral shearing of Avalonia along the Quebec Rentrant results in collision between Avalonia and New York Promontory (NYP). (D) Locking of inboard part of Avalonia against NYP causes shearing of outboard part of Avalonia mainly by dextral strike along Fundy Rift Zone (FRZ).

thick, extends at least $200 \mathrm{~km}$ along the orogen, and coarsens upwards as environments changed from coastal plain to distal to proximal alluvial plain in response to Acadian mountain building to the south. Wedge progradation was preceded by deepening of a foreland basin on the adjacent platform.

(2) Paleocurrents indicate persistent northward flow away from the rising mountains. Axial paleoflow changed from westward to eastward as the locus of major uplift migrated westward.

(3) Devonian successions in southern Gaspé record deposition of proximal to distal alluvium and lacustrine sediments within intermontane basins.

(4) Acadian deformation is attributed to convergence between Avalonia and the St. Lawrence Promontory of North America. Dextral shearing developed south of the promontory, and Avalonia translated along the continental margin, forming mountains and the mid-Gaspé clastic wedge as it impacted the St. Lawrence Promontory, and the Catskill wedge when it reached the New York Promontory.

(5) Carboniferous successions in Gaspé are dominated by allu- vial fan deposits and appear to be limited to paleovalleys.

(6) Carboniferous deposition resulted from fault tectonics, mainly dextral strike-slip in the Fundy Rift Zone, but dip-slip in Gaspé.

\section{ACKNOWLEDGEMENTS}

We thank Gary Yeo for suggesting the topic for this paper, Glen Stockmal, S.R. McCutcheon and an anonymous reviewer for comments on the manuscript, Julie Hayes for typing, Wayne Ritio for drafting, the Natural Sciences and Engineering Research Council of Canada for financial support, and Esso Resources for logistic help and permission to publish.

BOOTHROYD, J.C. and NUMMEDAL, D. 1978. Proglacial braided outwash: a model for humid alluvial fan deposits. In Fluvial Sedimentology. Edited by A.D. Miall. Canadian Society of Petroleum Geologists, Memoir 5, pp. 641-668.

BOUCOT, A.J., BRETT, C.E., OLIVER, W.A., and BLODGETT, R.B. 1986. Devonian faunas of the Sainte-Hélène Island breccia, 
Montréal, Québec, Canada. Canadian Joumal of Earth Sciences, 23. pp. 2047-2056.

BOUCOT, A.J., CUMMING, L.M., and JAEGER, H. 1967. Contributions to the age of the Gaspé Sandstone. Geological Survey of Canada, Paper 67-25.

BOURQUE, P.-A. 1977. Silurian and basal Devonian of northeastern Gaspé Peninsula. Quebec Department of Natural Resources, Special Paper ES-29.

BOURQUE, P.-A., BRISEBOIS, D., and MALO, M. In press. Middle Paleozoic rocks of Quebec and adjacent New Brunswick. In The Appalachian/Caledonian Region: Canada and Greenland. Edited by H. Williams. Geological Society of America, Decade of North American Geology, F-1.

BRADLEY, D.C. 1983. Tectonics of the Acadian Orogeny in New England and adjacent Canada. Journal of Geology, 91, pp. 381400.

BRISEBOIS, M. 1981. Géologie de la région de Gaspé. Québec Department of Energy and Resources, DPV-824.

CANT, D.J. and WALKER, R.G. 1976. Development of a braidedfluvial facies model for the Devonian Battery Point Sandstone, Quebec. Canadian Joumal of Earth Sciences, 13, pp. 102-119.

CASEY, J.F. and SAVCI, G. 1988. Subduction-obduction history recorded in the Bay of Islands and Coastal Complex ophiolites of western Newfoundland. Geological Association of Canada, Programme with Abstracts, 13, p. A18.

CHRISTIE-BLICK, N. and BIDDLE, K.T. 1985. Deformation and basin formation along strike-slip faults. In Strike-slip deformation, basin formation and sedimentation. Edited by K.T. Biddle and N. Christie-Blick. Society of Economic Paleontologists and Mineralogists, Special Publication 37, pp. 1-34.

DINELEY, D.L. and WILLIAMS, B.P.J. 1968. The Devonian continental rocks of the Lower Restigouche River, Quebec. Canadian Journal of Earth Sciences, 5, pp. 945-953.

EISBACHER, G.H. 1969. Displacement and stress field along part of the Cobequid Fault, Nova Scotia. Canadian Journal of Earth Sciences, 6, pp. 1095-1104.

HACQUEBARD, P.A. 1972. The Carboniferous of Eastern Canada. Seventh International Carboniferous Congress, Compte Rendu, 1, pp. 69-90.

HESSE, R. and SAWH, H. 1982. Escuminac Formation. In Paleozoic continental margin sedimentation in the Quebec Appalachians. Edited by R. Hesse, G.V. Middleton, and B.R. Rust. Intemational Association of Sedimentologists, Excursion Guidebook 7B, pp. 72-80.

HYDE, R.S. 1984. Geologic history of the Carboniferous Deer Lake Basin, west-central Newfoundland, Canada. In Atlantic Coast Basins. Edited by H.H.J. Geldsetzer. International Carboniferous Congress, Compte Rendu, 3, pp. 85-104.

IRVING, E. and STRONG, D.F. 1985. Paleomagnetism of rocks from Burin Peninsula, Newfoundland: Hypothesis of Late Paleozoic displacement of Acadia criticized. Journal of Geophysical Research, 90, pp. 1949-1962.

KEPPIE, J.D. 1985. The Appalachian collage. In The Caledonide Orogen - Scandinavia and related areas. Edited by D.G. Gee and B.A. Sturt. Wiley, New York, pp. 1217-1226.

LAURENT, R. and BELANGER, J. 1984. Geochemistry of SilurianDevonian alkaline basalt suites from the Gaspé Peninsula, Quebec Appalachians. Maritime Sediments and Atlantic Geology, 20, pp. 67-78.

LAWRENCE, D.A. 1986. Sedimentology of the Lower Devonian Battery Point Formation, eastern Gaspé Peninsula, Quebec, Canada. Ph.D. thesis, University of Bristol.
LAWRENCE, D.A. and WILLIAMS, B.P.J. 1987. Evolution of drainage systems in response to Acadian deformation: the Devonian Battery Point Formation. In Recent developments in fluvial sedimentology. Edited by F.G. Ethridge, R.M. Flores, and M.D. Harvey. Society of Economic Paleontologists and Mineralogists, Special Publication 39, pp. 287-300.

McCUTCHEON, S.R. and ROBINSON, P.T. 1987. Geological constraints on the genesis of the Maritimes Basin, Atlantic Canada. In Sedimentary basins and basin-forming mechanisms. Edited by $\mathrm{C}$. Beaumont and A.J. Tankard. Canadian Society of Petroleum Geologists, Memoir 12, pp. 287-297.

McGERRIGLE, H.W. 1950. The geology of eastern Gaspé. Quebec Department of Mines, Geological Report 35.

McGREGOR, D.C. 1973. Lower and Middle Devonian spores of eastern Gaspé, Canada. I. Systematics. Palaeontographica, 142B, pp. 1-77.

- 1977. Lower and Middle Devonian spores of eastem Gaspé, Canada. II. Biostratigraphy. Palaeontographica, 163B, pp. 111142.

McKERROW, W.S. and COCKS, L.R.M. 1977. The location of the Iapetus Ocean suture in Newfoundland. Canadian Journal of Earth Sciences, 14, pp. 488-499.

MOORES, E.M. 1982. Origin and emplacement of ophiolite. Reviews of Geophysics and Space Physics, 20, pp. 735-760.

ORVIG, S. 1957. Remarks on the vertebrate fauna of the lower Upper Devonian of Escuminac Bay, P.Q., Canada, with special reference to the porolepiform crossopterygians. Arkiv for Zoologi, 10, pp. $367-426$.

PAGEAU, Y. and PRICHONNET, G. 1976. Interpretation de la paléontologie et de la sédimentologie d'une coupe géologique dans la Formation du Battery Point (Dévonien Moyen), Grés de Gaspé. Le Naturaliste Canadien, 103, pp. 111-118.

POOLE, W.H., SANFORD, B.V., WILLIAMS, H., and KELLEY, D.G. 1970. Geology of southeastern Canada. In Geology and economic minerals of Canada. Edited by R.J.W. Douglas. Geological Survey of Canada, Economic Geology Report 1, pp. 227-304.

RUST, B.R. 1976. Stratigraphic relationships of the Malbaie Formation (Devonian), Gaspé, Québec. Canadian Journal of Earth Sciences, 13, pp. 1556-1559.

. 1978. Depositional models for braided alluvium. In Fluvial Sedimentology. Edited by A.D. Miall. Canadian Society of Petroleum Geologists, Memoir 5, pp. 605-625.

- 1981. Alluvial deposits and tectonic style: Devonian and Carboniferous successions in eastem Gaspé. In Sedimentation and Tectonics in alluvial basins. Edited by A.D. Miall. Geological Association of Canada, Special Paper 23, pp. 49-76.

- 1984a. Proximal braidplain deposits in the Middle Devonian Malbaie Formation of eastern Gaspé, Quebec, Canada. Sedimentology, 31, pp. 675-695.

- 1984b. The Cannes de Roche Formation: Carboniferous alluvial deposits in eastem Gaspé, Canada. In Atlantic Coast Basins. Edited by H.H.J. Geldsetzer. Intemational Carboniferous Congress, Compte Rendu, 3, pp. 72-84.

RUST, B.R. and KOSTER, E.H. 1984. Coarse alluvial deposits. In Facies Models. Edited by R.G. Walker. Geoscience Canada, Reprint Series 1, pp. 53-69.

SALAS, C.J. 1986. Braided fluvial architecture within a rapidly subsiding basin: The Pennsylvanian Cumberland Group southwest of Sand River, Nova Scotia. M.Sc. thesis, University of Ottawa.

SCHENK, P.E. 1978. Synthesis of the Canadian Appalachians: Caledonian-Appalachian Orogen of the North Atlantic Region. Geological Survey of Canada, Paper 78-13, pp. 111-136. 
SCHLUGER, P.R. 1973. Stratigraphy and sedimentary environments of the Devonian Perry Formation, New Brunswick, Canada and Maine, U.S.A. Bulletin of the Geological Society of America, 84, pp. 2533-2548.

SHULTZE, H.-P. and ARSENAULT, M. 1985. The Panderichthyid fish Elpistostege: a close relative of tetrapods? Palaeontology, 28, pp. 293-309.

SEVON, W.D. 1985. Nonmarine facies of the Middle and Late Devonian Catskill coastal alluvial plain. In The Catskill Delta. Edited by D.L. Woodrow and W.D. Sevon. Geological Society of America, Special Paper 201, pp. 79-90.

STOCKMAL, G.S., COLMAN-SADD, S.P., KEEN, C.E., O'BRIEN, S.J., and QUINLAN, G. 1987. Collision along an irregular margin: a regional plate tectonic interpretation of the Canadian Appalachians. Canadian Journal of Earth Sciences, 24, pp. 1098-1107.

TAPPONIER, P., PELTZER, G., and ARMIJO, R. 1986. On the mechanics of the collision between India and Asia. In Collision tectonics. Edited by M.P. Coward and A.C. Ries. Blackwells, Oxford, pp. 115-157.

THOMAS, R.G., SMITH, D.G., WOOD, J.M., VISSER, J., CALVERLEY-RANGE, E.A., and KOSTER, E.H. 1987. Inclined heterolithic stratification - Terminology, description, interpretation and significance. Sedimentary Geology, 53, pp. 123-179.

VAUCHEZ, A. 1987. Brevard fault zone, southern Appalachians: A medium-angle, dextral, Alleghanian shear zone. Geology, 15, pp. 669-672.

WEBB, G.W. 1969. Paleozoic wrench faults in Canadian Appalachians. In North Atlantic - geology and continental drift. Edited by M. Kay. American Association of Petroleum Geologists, Memoir 12, pp. 754-786.

WILLIAMS, H. 1979. Appalachian Orogen in Canada. Canadian Journal of Earth Sciences, 16, pp. 792-807.

WILLIAMS, H. and HATCHER, R.D. 1982. Suspect terranes and accretionary history of the Appalachian orogen. Geology, 10, pp. 530-536.

YEO, G.M. and GAO, R. 1986. Late Carboniferous dextral movement on the Cobequid-Hollow fault system, Nova Scotia: evidence and implications. Geological Survey of Canada, Paper 86-1A, pp. 399 410.

ZAITLIN, B.A. 1981. Sedimentology of the Pirate Cove, Fleurant and Bonaventure Formations of the western Baie des Chaleurs area, Maritime Canada: A depositional and tectonic model. M.Sc. thesis, University of Ottawa.

ZAITLIN, B.A. and RUST, B.R. 1983. A spectrum of alluvial deposits in the Lower Carboniferous Bonaventure Formation of westem Chaleur Bay area, Gaspé and New Brunswick, Canada. Canadian Journal of Earth Sciences, 20, pp. 1098-1110. 